\title{
Nonnutritive sweeteners in Brazil: current use and associated factors
}

\author{
Ana Paula Gines Geraldo ${ }^{1}$, Maria Elisabeth Machado Pinto-e-Silva ${ }^{2}$
}

DOI: http://dx.doi.org/10.7322/jhgd.122760

\begin{abstract}
:
Introduction: The consumption of added sugars has increased worldwide. To guide and encourage the implementation of public policies on the consumption of nonnutritive sweetener (NNS), it is necessary not only to identify the amount consumed of these products, but also the factors associated with their consumption.
\end{abstract}

Objective: This study aimed to identify the variables related to NNS consumption in São Paulo state, Brazil.

Methods: A cross-sectional study involving adult employees of two public Universities in São Paulo state, Brazil, was conducted. An online questionnaire was applied containing questions on the use of NNSs and information about demographic, socioeconomic, anthropometric and health characteristics. The statistical analyses performed included: the Chi-square test to determine association between explanatory and dependent variables, adopting a level of significance of $p<0.05$, and binary logistic regression calculating the Odds-Ratio $(\mathrm{OR})(\alpha=0.05)$. Results: A total of 1323 individuals took part in the study. The prevalence of NNS use was $53.3 \%$, proving higher among individuals between 30 and 60 years of age (83.3. The Chi-squared test revealed that the variables gender $(p=0.000)$, Diabetes Mellitus (DM) $(p=0.000)$, arterial hypertension $(p=0.008)$, difficulty controlling weight $(p=0.000)$, BMI $(p=0.000)$, income $(p=0.002)$ and age $(p=0.000)$ had a direct and significant association with NNS consumption. On the logistics regression model, the variables significantly associated with NNS consumption were gender (OR 1.3$)$, age $(\mathrm{OR}=2.59)$, $\mathrm{DM}(\mathrm{OR}=3.32)$, difficulty controlling weight (OR $=2.29$ ) and consumption of diet foods $(O R=3.87)$. These results revealed that women are $30 \%$ more likely to consume NNS than men and that being aged between 50 and 60 years increases the likelihood of consuming these products by 2.59 times. In addition, being diabetic, having difficulty controlling body weight, and consuming diet foods increase the likelihood of NNS consumption by 3.32; 2.29 and 3.97 times, respectively.

Conclusion: The majority of the population studied were consumers of NNSs. The variables gender, age, DM, difficulty controlling body weight, and consuming diet foods were all associated with the consumption of NNSs.

Keywords: nonnutritive sweeteners, obesity diabetes mellitus, body weight.

\section{INTRODUCTION}

Overweight and obesity represents a major challenge and a public health problem worldwide ${ }^{1}$. Obesity has been increasing in all countries. In 2014, 39\% of adults aged 18 years and older $(38 \%$ of men and $40 \%$ of women) were overweight and $11 \%$ of men and $15 \%$ of women worldwide were obese ${ }^{2}$. Among the environ- mental factors associated with overweight and obesity, food it is a direct determinant the increase of both ${ }^{3}$. Given this scenario, weight loss products that use nonnutritive sweeteners (NNS) are becoming increasingly popular with consumers seeking to control body weight. Among the most popular of these items are products containing NNS that diet foods and beverages without adding calories ${ }^{4}$. NNS is defined as an additive that has a higher

\footnotetext{
1 Universidade Federal de Santa Catarina, Departamento de Nutrição - Campus Universitário - Trindade. CEP: 88040-900. Florianópolis - SC - Brasil

2 Faculdade de Saúde Pública- USP, Departamento de Nutrição - Av. Dr. Arnaldo, 715. Cerqueira Cesar. CEP: 01246-904. São Paulo $\mathrm{SP}$ - Brasil.

Corresponding author: Ana Paula Gines Geraldo - E-mail: ana.paula.geraldo@ufsc.br

Suggested citation: Geraldo APG, Pinto-e-Silva MEM. Nonnutritive sweeteners in brazil: current use and associated factors. $J$ Hum Growth Develpment. 2016; 26(2): 297-306. DOI: http://dx.doi.org/10.7322/jhgd.122760.

Manuscript submitted: 18 Jul 2016, accepted for publication 14 Aug 2016.
} 
intensity of sweetness per gram than caloric sweeteners such as sucrose 5 .

The consumption of added sugars has increased worldwide ${ }^{6}$. Data on food consumption in Brazil point to a high prevalence in inadequate intake of free sugar, 10\% above the total energy $(67.0 \% \text { for men and women })^{7}$. The latest guidelines from the World Health Organization state that the intake of sugars should not exceed $10 \%$ of the total energetic value of the diet, and preferably should not exceed $5 \%$, in both adults and children ${ }^{8}$. In this context, NNS can replace the sugar sweet taste.

Since saccharin discovery in the late 1800 s, NNS have been used by consumers for the control of blood glucose and energy consumption ${ }^{9}$. The literature shows that the use of dietary sweetener is higher among diabetics, hypertensive and obese individuals ${ }^{10}$.

The development of new eating habits and the current trends in production and consumption, can impact on health, environment and social ${ }^{11}$. To guide and encourage the implementation of public policies on the consumption of NNS, it is necessary not only to identify the amount consumed of these products, but also the factors associated with their consumption. In this sense, the present study aimed to describe the frequency of consumption of NNS by Brazilian adults and to assess factors associated with their consumption.

\section{METHODS}

\section{Study population}

This is an observational, transversal trial, aiming to characterize the behavior in the consumption of NNS. The trial was performed with adults (aged $\geq 20$ years) e and the elderly; teaching staff and non-teaching staff of two public universities in the state of São Paulo, Brazil. Data collecting took place on February and March 2012. All employees were invited to participate in the research through electronic messages.

This study adopted the following eligibility criteria: adults and elderly (aged $\geq 20$ years), body mass index (BMI) $18.5-24.99 \mathrm{~kg} / \mathrm{m}^{2}$ (appropriate weight) and BMI $>24.99 \mathrm{~kg} / \mathrm{m}^{2}$ (overweight), teaching staff and nonteaching staff of the universities involved in the trial. In addition, the study was delimited by the following criteria: prior agreement and cooperation of the directors of each institute of the universities involved and the participant's compliance with the Informed Consent present on the first page of the questionnaire.

The total number of teaching and non-teaching active employees in 2011 was 33,070. The minimum sample size was calculated using the equation: $n=Z^{2}{ }_{\alpha / 2} \cdot p \cdot q / E^{2}$

The $p$ and $q$ value of 0.5 was adopted because the population proportion of NNS consumers in the state of São Paulo is not known. The confidence level established was $99 \%$, the critical value associated with that confidence level $\left(Z_{\alpha / 2}\right)$ is 2.575 and the standard error stipulated for the calculation was $5 \%$. Considering the possibility of losses, $20 \%$ were added so that there wa reduction in the sample size, which finally consisted of 795 subjects.
The directorates of all units of the universities involved in the study were contacted and agreed to the disclosure of the research and participation of the employees. Thus, all employees were invited to participate in the study through electronic messages.

\section{Anthropometry}

Body Mass Index (BMI) was calculated by dividing the referred weight $(\mathrm{kg})$ by referred height squared $\left(\mathrm{m}^{2}\right)$. Armed with this index, the classification of the nutritional status of the participants was made in BMI percentiles per age and was categorized according to the World Health Organization ${ }^{12}$. For subjects aged greater than or equal to 60 years, the classification was made according to Lipschitz ${ }^{13}$.

\section{NNS intake}

The instrument was developed based on the study of Zanini et al ${ }^{10}$. Survey Monkey (https://pt.surveymonkey. $\mathrm{com} /$ ) tool was used to prepare the questionnaire. An online questionnaire was applied containing questions on the use of NNSs and information about demographic, socioeconomic, anthropometric and health characteristics The questionnaire was pre-assessed with 25 employees of a state university in the city of São Paulo and adjustments were made according to the results.

The web link of the questionnaire was made available to participants. In order not to allow a participant to answer it more than once, only one access number for each computer IP used was released.

\section{Statistical analysis}

All analyses were performed using SPSS software version 22.0. The analysis of the results was divided into two steps: (1) Characterization of sociodemographics and consumption behavior of NNS e diet food, as well as their use and knowledge, performed through ratios and means, standard deviation and medians. (2) The analysis of the determinants of consumption of NNS and diet food (dependent variables) was performed through univariate and multiple logistic regression analysis.

The survey of the features that predisposed the participant to consume NNS and industrialized light/diet products was prepared according to the following steps: initially univariate models were designed, being eligible the variables that showed an association $(p<0.20)$ by ChiSquare test for logistic regression. Independent variables that showed some association $(\mathrm{p}<0.20)$ were transferred to the following step of multiple logistic regression, each one placed in the model by order of magnitude of odds ratio and eliminating the variables that showed no significance. The categories with odds ratios (ORs) higher than 1.0 were considered risk-predisposing factors and the categories with ORs lower than 1.0 were considered protection factors.

The research was approved by the Institutional Review Board from School of Public Health of the University of São Paulo and the participation of the subjects relied on the acceptance of the informed consent form. 


\section{RESULTS}

1323 subjects participated in the study (Table $1)$. The average age of the population was 41.49 years old ( $\mathrm{sd}=11.33)$. Most subjects were women $(62.7 \%)$, married $(58.2 \%)$, and had more than 16 years of education $(74.1 \%) .77 .2 \%$ reported having an income $\geq 5$ MW. Regarding physical activity, it was observed that the majority practiced it 2 to 3 times per week $(33.3 \%)$.

Table 1: Characterization of the sample of employees of public university institutions. São Paulo, Brazil, 2012

\begin{tabular}{|c|c|c|c|}
\hline Variable & & n & $\%$ \\
\hline \multirow[t]{5}{*}{ Age } & 20-29 years old & 235 & 17.8 \\
\hline & 30-39 years old & 354 & 26.8 \\
\hline & 40-49 years old & 370 & 28.0 \\
\hline & $50-59$ years old & 298 & 22.5 \\
\hline & $\geq 60$ years old & 66 & 5.0 \\
\hline \multirow[t]{2}{*}{ Gender } & Male & 493 & 37.3 \\
\hline & Female & 830 & 62.7 \\
\hline \multirow[t]{4}{*}{ Marital status } & Single & 407 & 30.8 \\
\hline & Married & 770 & 58.2 \\
\hline & Divorced & 119 & 9.0 \\
\hline & Widower & 27 & 2.0 \\
\hline \multirow[t]{3}{*}{ Years of education } & Up to 11 years & 80 & 6.0 \\
\hline & 12 to 15 years & 263 & 19.9 \\
\hline & $\geq 16$ years & 980 & 74.1 \\
\hline \multirow[t]{5}{*}{ Physical activity } & Never & 307 & 23.2 \\
\hline & 1 - 2 times per month & 214 & 16.2 \\
\hline & 1 time per week & 144 & 10.9 \\
\hline & 2 - 3 times per week & 440 & 33.3 \\
\hline & 4 - 7 times per week & 218 & 16.5 \\
\hline \multirow[t]{3}{*}{ Income } & Up to $4 \mathrm{MW}$ & 267 & 20.7 \\
\hline & 5 to $10 \mathrm{MW}$ & 542 & 42.1 \\
\hline & $\geq 10 \mathrm{M}$ & 479 & 37.2 \\
\hline \multirow[t]{3}{*}{ BMI $\left(k g / m^{2}\right)$} & Up to 24.9 & 611 & 46.2 \\
\hline & $25.0-29.9$ & 470 & 35.5 \\
\hline & $\geq 30.0$ & 242 & 18.3 \\
\hline \multirow{2}{*}{ Hypertension } & No & 1152 & 87.1 \\
\hline & Yes & 171 & 12.9 \\
\hline \multirow[t]{2}{*}{ DM } & No & 1241 & 93.8 \\
\hline & Yes & 82 & 6.2 \\
\hline \multirow[t]{2}{*}{ Consumption NNS } & No & 612 & 46.3 \\
\hline & Yes & 711 & 53.7 \\
\hline \multirow[t]{2}{*}{ Consumption of diet food } & No & 605 & 46.5 \\
\hline & Yes & 695 & 53.5 \\
\hline
\end{tabular}

It was observed that subjects who never performed physical activities are mostly those with trouble in maintaining body weight $(61.9 \% ; \mathrm{p}=0.001)$ and are overweight $(35.5 \%)$ or obese $(24.4 \%)(p=0.009)$. Physical activity practiced 5-7 times a week was more prevalent among those who have no trouble in maintaining body weight (53.2\%) and eutrophic (50.9\%). Only $13.3 \%$ of the obese subjects practice physical activity with that frequency. When physical practice is assessed grouping "never" to "once weekly", the prevalence among eutrophic subjects was $45.7 \%, 51.5 \%$ overweight and $59.5 \%$ obese, i.e., the higher the degree of excess weight, the lower the frequency of physical activity.
$53.8 \%$ had some degree of overweight (BMI $\geq 25.0)$. The mean weight of the sample was $74.03 \mathrm{~kg}(\mathrm{sd}=16.45 \mathrm{~kg})$ and mean BMI $26.18(\mathrm{sd}=4.64)$, and $53.7 \%$ of the studied sample stated being consumers of NNS.

The characteristics of NNSs consumers are shown in Table 2. The consumers were mostly women (67.5\%), aged between 40 and 59 years $(56.7 \%)$ with a mean of 43.2 years $(\mathrm{sd}=10.86)$, married $(60.8 \%)$ and $\geq 12$ years of education $(93.8 \%)$. Subjects who practice physical activity $2-3$ times a week were the ones most consuming NNS. The mean weight was $72.03 \mathrm{~kg}(\mathrm{sd}=15.55)$ and the mean BMI $25.26 \mathrm{~kg} / \mathrm{m}^{2}(\mathrm{sd}=4.3)$. We found a prevalence of $63.3 \%$ of overweight $(\mathrm{BMI} \geq 25.0)$ among NNS consumers. 
Table 2: Characterization of consumers of nonnutritive sweeteners from university institutions. São Paulo, Brazil, 2012

\begin{tabular}{|c|c|c|c|}
\hline Variable & & n & $\%$ \\
\hline \multicolumn{4}{|l|}{ Age } \\
\hline & $20-29$ years old & 82 & 11.5 \\
\hline & 30 - 39 years old & 189 & 26.6 \\
\hline & $40-49$ years old & 210 & 29.5 \\
\hline & 50 - 59 years old & 193 & 27.1 \\
\hline & $\geq 60$ years old & 37 & 5.2 \\
\hline \multirow[t]{2}{*}{ Gender } & Male & 231 & 32.5 \\
\hline & Female & 480 & 67.5 \\
\hline \multirow[t]{4}{*}{ Marital status } & Single & 196 & 27.6 \\
\hline & Married & 433 & 60.9 \\
\hline & Divorced & 66 & 9.3 \\
\hline & Widower & 16 & 2.3 \\
\hline \multirow[t]{3}{*}{ Years of education } & Up to 11 years & 44 & 6.2 \\
\hline & $12-15$ years & 130 & 18.3 \\
\hline & $\geq 16$ years & 537 & 75.5 \\
\hline \multirow{5}{*}{ Physical activity } & Never & 162 & 22.8 \\
\hline & $1-2$ times per month & 112 & 15.8 \\
\hline & 1 time per week & 65 & 9.1 \\
\hline & 2 - 3 times per week & 239 & 33.6 \\
\hline & $4-7$ times per week & 133 & 18.7 \\
\hline \multirow[t]{3}{*}{ Income } & Up to $4 \mathrm{MW}$ & 118 & 17.1 \\
\hline & $5-10 \mathrm{MW}$ & 301 & 43.6 \\
\hline & $>10 \mathrm{MW}$ & 271 & 39.3 \\
\hline \multirow[t]{3}{*}{ BMI $\left(\mathrm{kg} / \mathrm{m}^{2}\right)$} & $\leq 24.9$ & 282 & 39.7 \\
\hline & $25.0-29.9$ & 269 & 37.8 \\
\hline & $\geq 30.0$ & 160 & 22.5 \\
\hline \multirow[t]{2}{*}{ Diabetes Mellitus } & No & 641 & 90.2 \\
\hline & Yes & 70 & 9.8 \\
\hline \multirow[t]{2}{*}{ Hypertension } & No & 603 & 84.8 \\
\hline & Yes & 108 & 15.2 \\
\hline \multirow[t]{2}{*}{ Difficulty maintaining body weight } & No & 251 & 35.3 \\
\hline & Yes & 460 & 64.7 \\
\hline \multirow[t]{2}{*}{ Consumption of diet food } & No & 206 & 29.6 \\
\hline & Yes & 490 & 70.4 \\
\hline
\end{tabular}

The difficulty in maintaining body weight was reported by $64.8 \%$ of NNS consumers and among the main reasons for its use, the following stood out: "Not willing to get fat" (41.4\%), "Willing to save calories to be consumed in other food" (26.8\%).

Table 3 shows the variables that were associated with the consumption of NNS. Gender, age, income, BMI, physical activity, DM, hypertension, difficulty maintaining body weight and consumption of diet food were statistically different between consumers and non-consumers.

Also according to Table 3, there was a higher proportion of females among consumers $(p=0.000)$ and the highest frequency of consumption occurs in the age group 30-59 years old $(\mathrm{p}=0.000)$. Among subjects aged 20 to 29 years, there was a higher prevalence of non-consumers $(25.0 \%)$.

The income above $4 \mathrm{MW}$ was found to be associated with the consumption of NNS $(p=0.002)$, and $82.9 \%$ of consumers are in that income range. $\mathrm{BMI} \geq 25.0$ (over- weight and obese) had a positive association with the consumption of NNS $(p=0.000)$. Among consumers, 39.7\% did not have any degree of overweight, while among nonconsumers this number is 1.36 times higher (53.8\%).

Regarding physical activity, the highest prevalence of NNS consumers was found in frequency of 2 to 3 times per week $(p=0.000)$. In addition, in the frequency of 4 to 7 times per week the proportion of consumers was $34.5 \%$ higher compared to non-consumers.

Subjects who consume diet food showed a prevalence of consumption of NNS 2.1 times higher than those who do not consume it $(\mathrm{p}=0.000)$. Likewise, the consumption of NNS was 1.68 times higher among subjects who have difficulty maintaining their body weight $(p=0.000)$. There was no statistically significant difference within marital status and years of education.

On Table 4, univariate and multiple logistic regression models are presented, according to factors associ- 
Table 3: Distribution and association of demographic, social-economic, behavioral, nutritional ad health variables with the consumption of NNSs. São Paulo, Brazil, 2012

\begin{tabular}{|c|c|c|c|c|c|}
\hline \multirow{2}{*}{ Variable } & \multicolumn{2}{|c|}{ Consumer } & \multicolumn{2}{|c|}{ Non-consumer } & \multirow{2}{*}{$\mathrm{p}^{*}$} \\
\hline & $\mathbf{n}$ & $\%$ & $\mathbf{n}$ & $\%$ & \\
\hline \multicolumn{6}{|l|}{ Gender } \\
\hline Male & 231 & 32.5 & 262 & 42.8 & 0.000 \\
\hline Female & 480 & 67.5 & 350 & 57.2 & \\
\hline \multicolumn{6}{|l|}{ Age } \\
\hline $20-29$ years old & 82 & 11.5 & 153 & 25.0 & 0.000 \\
\hline $30-39$ years old & 189 & 26.6 & 165 & 27.0 & \\
\hline $30-49$ years old & 210 & 29.5 & 160 & 26.1 & \\
\hline $50-59$ years old & 193 & 27.1 & 105 & 17.2 & \\
\hline$\geq 60$ years old & 37 & 5.2 & 29 & 4.7 & \\
\hline \multicolumn{6}{|l|}{ Income } \\
\hline Up to $4 \mathrm{MW}$ & 118 & 17.1 & 149 & 24.9 & 0.002 \\
\hline 5 to $10 \mathrm{MW}$ & 301 & 43.6 & 241 & 40.3 & \\
\hline$>10 \mathrm{MW}$ & 271 & 39.3 & 208 & 34.8 & \\
\hline Physical activity & 162 & 22.8 & 145 & 23.7 & 0.054 \\
\hline Never & 112 & 15.8 & 102 & 16.7 & \\
\hline 1 a 2 times per month & 65 & 9.1 & 79 & 12.9 & \\
\hline 1 time per week & 239 & 33.6 & 201 & 32.8 & \\
\hline 2 a 3 times per week & 133 & 18.7 & 85 & 13.9 & \\
\hline \multicolumn{6}{|l|}{4 a 7 times per week } \\
\hline DM & 641 & 90.2 & 600 & 98.0 & 0.000 \\
\hline No & 70 & 9.8 & 12 & 2.0 & \\
\hline \multicolumn{6}{|l|}{ Yes } \\
\hline Hypertension & 603 & 84.8 & 549 & 89.7 & 0.008 \\
\hline No & 108 & 15.2 & 63 & 10.3 & \\
\hline \multicolumn{6}{|l|}{ Yes } \\
\hline \multicolumn{6}{|c|}{ Difficulty maintaining body weight } \\
\hline No & 251 & 35.3 & 376 & 61.4 & 0.000 \\
\hline Yes & 460 & 64.7 & 236 & 38.6 & \\
\hline \multicolumn{6}{|c|}{ Consumption of diet food } \\
\hline No & 206 & 29.6 & 399 & 66.1 & 0.000 \\
\hline Yes & 490 & 70.4 & 205 & 33.9 & \\
\hline \multicolumn{6}{|l|}{ Years of education } \\
\hline Up to 11 years & 44 & 6.2 & 36 & 5.9 & 0.294 \\
\hline 12 to 15 years & 130 & 18.3 & 133 & 21.7 & \\
\hline 16 years or over & 537 & 75.5 & 443 & 72.4 & \\
\hline
\end{tabular}

* Descriptive level of the test of association by Chi-square.

ated to NNS consumption. The results showed that being diabetic, having difficulty maintaining body weight and consuming diet food increase the chance of consuming NNS in $3.32 ; 2.29$ and 3.87 respectively. Women were 1.3 times more likely to consume NNS compared to men. In addition, subjects $50-59$ years old were 2.59 times more likely to consume sNNS compared to subjects $20-29$ years old. In short, subjects who reported consuming more NNS are those who are diabetic, with difficulty maintaining body weight, consuming diet food, women and mostly aged within 50 and 59 years.

\section{DISCUSSION}

The findings of the present work showed that the magnitude of the frequency (53.5\%) of use of NNS found in this study is much higher than that found in the Bra- zilian literature. These findings contrast with the results found by Zanini et al. ${ }^{10}$, which found prevalence of NNS use of $19.0 \%$ in subjects from Pelotas (RS), being higher for women. It is likely that this difference is because those are studies performed in different Brazilian regions, with cultural differences that influence eating habits, a more balanced male to female ratio and lower prevalence of high income in the study in Pelotas.

Information on the amounts of NNS in beverages and foods is limited and not easily accessible ${ }^{5}$ making it difficult to compare the data obtained in this study with other populations. Bär and Biermann ${ }^{14}$ estimated that in $199235.9 \%$ of the participants ingested one or more NNSs on the examination day.

The prevalence of DM among NNS consumers was $9.8 \%$ in the studied sample, showing that the intake of NNS is not restricted to people with diabetes, who often replace sugar with NNS. 
Table 4: Analysis of univariate and multiple logistic regression, according to factors associated to consumption of NNSs, São Paulo, Brazil, 2012

\begin{tabular}{|c|c|c|c|c|c|}
\hline \multirow{2}{*}{ Variables } & \multirow{2}{*}{ Categories } & \multicolumn{2}{|c|}{ Univariate } & \multicolumn{2}{|c|}{ Final model and the block } \\
\hline & & OR raw & $\mathrm{Cl}_{95 \%}$ & OR adjusted & $\mathrm{Cl}_{95 \%}$ \\
\hline \multirow[t]{3}{*}{ Income } & Up to $4 \mathrm{MW}$ & 1.0 & - & - & - \\
\hline & 5-10 MW & 1.58 & $1.17-2.12$ & - & - \\
\hline & $>10 \mathrm{MW}$ & 1.64 & $1.22-2.22$ & - & - \\
\hline \multirow[t]{2}{*}{ Gender } & Male & 1.0 & - & 1.0 & - \\
\hline & Female & 1.55 & $1.24-1.95$ & 1.30 & $1.01-1.69$ \\
\hline \multirow[t]{5}{*}{ Age group } & $20-29$ years old & 1.0 & - & 1.0 & - \\
\hline & $30-39$ years old & 2.14 & $1.52-3.00$ & 1.81 & $1.24-2.63$ \\
\hline & $40-49$ years old & 2.45 & $1.75-3.43$ & 1.96 & $1.35-2.85$ \\
\hline & $50-59$ years old & 3.43 & $2.40-4.91$ & 2.59 & $1.73-3.86$ \\
\hline & $\geq 60$ years old & 2.38 & $1.37-4.15$ & 1.94 & $1.05-6.30$ \\
\hline \multirow[t]{2}{*}{ DM } & No & 1.0 & - & - & - \\
\hline & Yes & 5.46 & $2.93-10.17$ & 1.0 & - \\
\hline \multirow[t]{2}{*}{ Hypertension } & No & 1.0 & - & 3.32 & $1.71-6.43$ \\
\hline & Yes & 1.56 & $1.12-2.17$ & - & - \\
\hline \multirow[t]{2}{*}{ Difficulty maintaining Body weight } & No & 1.0 & - & - & - \\
\hline & Yes & 2.92 & $2.33-3.65$ & 1.0 & - \\
\hline \multirow[t]{3}{*}{ BMI (kg/m2) } & $\leq 24.9$ & 1.0 & - & 2.29 & $1.79-2.93$ \\
\hline & $25,9-29.9$ & 1.56 & $1.22-1.99$ & - & - \\
\hline & $\geq 30.0$ & 2.28 & $1.67-3.10$ & - & - \\
\hline \multirow[t]{5}{*}{ Physical activity } & Never & 1.0 & - & - & - \\
\hline & 1- 2 times/month & 0.98 & $0.69-1.39$ & - & - \\
\hline & 1 time/week & 0.74 & $0.49-1.10$ & - & - \\
\hline & 2- 3 times/week & 1.06 & $0.80-1.42$ & - & - \\
\hline & 4-7 times/week & 1.40 & $0.98-1.99$ & - & - \\
\hline \multirow[t]{2}{*}{ Consumption of diet food } & No & 1.0 & - & 1.0 & - \\
\hline & Yes & 4.63 & $3.66-5.85$ & 3.87 & 3.03 \\
\hline \multirow[t]{3}{*}{ Years of education } & Up to 11 years & 1.0 & - & - & -4.95 \\
\hline & $12-15$ years & 0.80 & $0.48-1.32$ & - & - \\
\hline & $\geq 16$ years & 0.99 & $0.63-1.57$ & - & - \\
\hline \multirow[t]{4}{*}{ Marital status } & Single & 1.0 & - & - & - \\
\hline & Married & 1.38 & $1.09-1.76$ & - & - \\
\hline & Widower & 1.57 & $0.71-3.46$ & - & - \\
\hline & Divorced & 1.34 & $0.89-2.02$ & - & - \\
\hline
\end{tabular}

The results on the factors associated with consumption of NNS found by Zanini et al. ${ }^{10}$ in the city of Pelotas, Brazil, were similar to the results in this study, where it was observed that the prevalence of consumption of NNS was higher among women with higher socioeconomic status (classes A and B) and overweight. However, the results were not in agreement with regard to marital status, since the authors found that divorced subjects and widowers were the largest consumers of NNS, while in the present study there was no significant statistical difference for this variable.

A survey that examined the trends in consumption of foods and beverages with NNS among Americans aged $\geq 2$ years by using the U.S. Department of Agriculture Nationwide Food Consumption Survey for 1965, 1977 to 1978, and 1989 to 1991 and the National Health and Nutrition Examination Survey (NHANES) for 1999 to 2000, 2001 to 2002, and 2003 to 2004 found that the consump- tion of NNS in both beverages and foods increased over time. The survey data indicate that, on any given day, $15 \%$ of the U.S. population consumed NNS in 2003 to 2004 in comparison with $3 \%$ in $1965^{15}$.

In Brazil, the participation of "added sugars" (from refined sugar and processed foods) available in Brazilian households is $16.7 \%$ of total calories ${ }^{7}$ exceeding the maximum limit of $10 \%$ recommended by the World Health Organization. This research found that scenario in all income classes. However, when only refined sugar is considered, the participation is lower in the upper income quintile. In the present study, we found that the prevalence of consumption of NNSs is higher among subjects with income $\geq$ five minimum wages ( $R \$ 1,230.00)$, suggesting that in higher income ranges, refined sugar may be being replaced by NNS.

In recent years, the ideal image of women has become unrealistically thin, while the ideal image of men 
has become unrealistically muscular. The exposure to these unrealistic models is associated with body dissatisfaction in both women and men, particularly among those who engage in social comparison and internalize the ideals. The body types shown in the media as ideal vary more for men than women, and there is more frequent depiction of objectified images of women compared to men. Thus, there is sociocultural pressure to aspire to unrealistic body ideals, especially for women ${ }^{16}$.

The results from this work showed that women are the largest consumers of NNS, probably bur to the higher concern with aesthetics, which motivates them to not want to get fat, and thus replace the sugar by NNSs. It should be noted, however, that women $(21.6 \%)$ have affinity for the sweet taste, according to data from Surveillance System for Protective and Risk Factors via Telephone Survey (VIGITEL) for the state of São Paulo ${ }^{17}$.

It is noteworthy that subjects who are overweight and have difficulty maintaining body weight consume more NNS compared to eutrophic ones, however it is not possible to establish a causality relationship, i.e., we cannot state whether subjects consume NNS because they are overweight or whether it is the consumption of NNS that can contribute to body weight gain.

The strategy of replacing sucrose with NNSs is widely used by subjects because of the known potential for reducing caloric intake from diet foods and beverages, maintaining a high acceptability standard ${ }^{18}$. If non-nutritive sweeteners are used as substitutes for higher energy yielding sweeteners, they can have the potential to aid in weight management ${ }^{15}$.

Findings regarding the effects of NNSs on energy intake and body weight have been controversial. Most studies indicate that several NNSs may assist with obesity and type 2 diabetes. Other studies suggest that several NNSs may lead to weight gain ${ }^{19,20}$. The sweet taste dissociated from the caloric content of the food can cause activation of mechanisms of food reward, and may boost the desire for $\operatorname{sugar}^{20}$. Feijó et al. ${ }^{21}$ studied the effect on body weight of addition of NNS to the diet of rats and found that greater weight gain was promoted by the use of saccharin or aspartame compared to sucrose $\mathrm{e}^{22-24}$, and that this weight gain was not related to calorie intake. Swithers et al. ${ }^{25}$ suggest that there are negative consequences for weight control from the consumption of NNS, especially among subjects who use them to control body weight and women who consume a "westernized" diet.

Many NNS consumers do not exercise. This shows the need for proper guidance on the importance of lifestyle changes for loss or maintenance of body weight. It is important to highlight that the replacement of added sugar with NNS alone may not result in weight loss, since physical exercise is essential for the treatment of obesity ${ }^{23}$. The use of NNS can provide benefits toward weight reduction in the individual patient, and may depend on the characteristics of their baseline diet, associated changes, or dietary compensation involved with ingestion of NNS, and the degree of compliance with a more complete weight loss program ${ }^{24}$. This information is of great importance for health professionals to guide efficiently the inclusion of NNS in the diet of the subjects and highlights the need for a multidisciplinary team in the treatment of obesity.

The higher frequency of physical activity was associated with consumption of NNS. This fact is relevant, since these individuals combine physical exercises to NNS consumption possibly for the control of body weight. However, consumption of NNS is not determinant in the practice if physical activity, since many consumers are not considered active.

The multiple regression analysis identified gender, age, DM, difficulty in maintaining weight and the consumption of dietary foods as variables associated with consumption of NNS. In the construction of the regression analysis, it can be seen that when the variables included difficulty maintaining weight and BMI classification, the latter variable would lose significance, because both are closely related.

The consumption of diet food was the most important element in the regression, followed by DM, the difficulty in maintaining weight and age group between 50 and 59 years old.

Consumption of diet food increases by 3.87 times the chance of consuming NNS. In fact, most of the diet food consumers in the studied sample also consume NNS. Possibly these subjects combine the use of these two products to control their calorie intake and/or treatment of DM.

The presence of DM greatly increases the chance of consuming NNS. This is because the use of this product is usually part of the dietary recommendations for the treatment of this disease. At this time, there is plausibility for a health benefit from replacing added sugars and the calories they provide with NNS for the purpose of glycemic control and diabetes prevention or management ${ }^{25}$.

Having difficulty maintaining body weight increases the chance of consuming NNS, probably because subjects who have this characteristic replace sugar with NNS to decrease calorie intake. This result highlights the importance of studying the eating attitudes, including individuals who are overweight, for proper guidance on the use of NNS replacing sugar. According to the American Dietetic Association, dysfunctional eating attitudes involve rigid notions of healthy eating, guilt, fear and anxiety related to food choices ${ }^{26}$.

In terms of age group, the greater chance of consuming NNS is in the range 50-59 years old (2.59 times), although all age groups showed an increased chance in the consumption of these products compared to those aged 20 to 29 years. In the studied sample, it was observed that the higher prevalence of obesity and DM was found in the age group with the highest chance of consuming NNS (50-59 years old). Of all the diseases, type 2 diabetes mellitus is the disease most affecting a large number of elderly subjects and its complications take a major toll on the quality of life of the elderly and the healthcare costs to the society ${ }^{27}$.

In view of these results, we can say that, in the studied sample, with the increase in the age, the greater the need to control body weight and DM, and thus the consumption of NNS and diet food is increased.

Moreover, the chance of women to consume NNS is $30 \%$ higher compared to men. As already mentioned, women have greater concern with aesthetics and 
are under pressure that the social environment imposes with the standards of beauty set out, represented as a thin body. This fact justifies the increased use of these products by women.

Some limitations of the study should be considered. Based on the results of this study, with a cross-sectional design and non-probabilistic and very specific sample (non-teaching staff and teaching staff from universities), the data obtained cannot be extrapolate for the entire adult population of the state of São Paulo. Moreover, we used data related to variables that suffer many influences in this type of collection, such as body weight, height and morbidity. It is noteworthy that the validation of anthropometric data was performed to minimize this bias.

The questionnaire, administered online, also sets a limitation in the study, such as the sample being limited to those who have internet access, the impersonality and the lower reliability of the data. On the other hand, Galante and $\mathrm{Colli}^{28}$ claim that computerized questionnaires completed on the Internet are easily used and have several advantages, such as immediate verification of inconsistencies in the answer or missed fields. In fact, these benefits of using the online questionnaire are relevant, especially in samples with a lot of individuals or when it is necessary to get data from distant populations.

Based on the results obtained it can be concluded that the frequency of NNS consumption is high, with more than half of the population studied consuming these products. The greater chance of consuming them is among females, aged 50 years and above and who seek these products to control body weight or Diabetes Mellitus.

\section{REFERENCES}

1. Popa S, Moţa M, Popa A, Moţa E, Serafinceanu C, Guja C, et al. Prevalence of overweight/obesity, abdominal obesity and metabolic syndrome and atypical cardiometabolic phenotypes in the adult Romanian population: PREDATORR study. J Endocrinol Invest. 2016; 39(9):1045-53. DOI: http://dx.doi.org/10.1007/ s40618-016-0470-4

2. World Health Organization (WHO). Global status report on noncommunicable diseases 2014. Geneva: World Health Organization; 2014.

3. Abreu LC. Condições relacionadas à obesidade secundária na interface do crescimento e desenvolvimento. J Hum Growth Dev. 2011;21(1):7-10. DOI: http://dx.doi.org/10.7322/jhgd.19990

4. Hill SE, Prokosch ML, Morin A, Rodeheffer CD. The effect of non-caloric sweeteners on cognition, choice, and post-consumption satisfaction. Appetite. 2014;83:82-8. DOI: http://dx.doi.org/10.1016/j.appet.2014.08.003

5. Gardner $\mathrm{C}$ et al. Nonnutritive sweeteners: current use and health perspectives: a scientific statement from the American Heart Association and the American Diabetes Association. Circulation. 2012;126(4):509-19. DOI: http://dx.doi.org/10.1161/CIR.0b013e31825c42ee

6. Tappy L, Lê KA. Metabolic effects of fructose and the worldwide increase in obesity. Physiol Rev. $2010 ; 90$ (1):23-46. DOI: http://dx.doi.org/10.1152/physrev.00019.2009

7. Costa Louzada ML, Martins AP, Canella DS, Baraldi LG, Levy RB, Claro RM, et al. Ultra-processed foods and the nutritional dietary profile in Brazil. Rev Saúde Pública. 2015;49: 38. DOI: http://dx.doi.org/10.1590/ S0034-8910.2015049006132

8. World Health Organization (WHO). Guideline: Sugars intake for adults and children. Geneva: World Health Organization; 2015.

9. Fitch C, Keim KS; Academy of Nutrition and Dietetics. Position of the Academy of Nutrition and Dietetics: use of nutritive and nonnutritive sweeteners. J Acad Nutr Diet. 2012; 112(5):739-58. DOI: http://dx.doi. org/10.1016/j.jand.2012.03.009

10. Zanini RV, Araújo CL, Martínez-Mesa J. Use of diet sweeteners by adults in Pelotas, Rio Grande do Sul State, Brazil: a population-based study. Cad Saúde Pública. 2001;27 (5): 924-34. DOI: http://dx.doi. org/10.1590/S0102-311X2011000500010

11. Feferbaum R, Abreu LC, Leone C. Fluid intake patterns: an epidemiological study among children and adolescents in Brazil. BMC Public Health. 2012;12:1005. DOI: http://dx.doi.org/10.1186/1471-2458-12-1005

12. World Health Organization (WHO). Obesity: preventing and managing the global epidemic. Geneva: World Health Organization; 2000.

13. Lipschitz DA. Screening for nutritional status in the elderly. Prim Care. 1994;21(1):55-67.

14. Bär AL, Biermann C. Intake of intense sweeteners in Germany. Z Ernahrungswiss. 1992; 31(1):25-39. DOI: http://dx.doi.org/10.1007/BF01612550

15. Mattes RD, Popkin BM. Nonnutritive sweetener consumption in humans: effects on appetite and food intake and their putative mechanisms. Am J Clin Nutr. 2009;89(1):1-14. DOI: http://dx.doi.org/10.3945/ ajcn.2008.26792 
16. Murnen SK, Poinsatte K, Huntsman K, Goldfarb J, Glaser D. Body ideals for heterosexual romantic partners: Gender and sociocultural influences. Body Image. 2015;12: 22-31. DOI: http://dx.doi.org/10.1016/j. bodyim.2014.09.005

17. Malta DC, Campos MO, Oliveira MM, Iser BPM, Bernal RTI, Claro RM, et al. Prevalência de fatores de risco e proteção para doenças crônicas não transmissíveis em adultos residentes em capitais brasileiras, 2013. Epidemiol Serv Saúde. 2015; 24(3):373-87. DOI: http://dx.doi.org/10.5123/S1679-49742015000300004

18. Fernstrom JD. Non-Nutritive Sweeteners and Obesity. Annu Rev Food Sci Technol. 2015; 6: 119-136. DOI: http://dx.doi.org/10.1146/annurev-food-022814-015635

19. Mitsutomi K, Masaki T, Shimasaki T, Gotoh K, Chiba S, Kakuma T, et al. Effects of a nonnutritive sweetener on body adiposity and energy metabolism in mice with diet-induced obesity. Metabolism. 2014;63(1):6978. DOI: http://dx.doi.org/10.1016/j.metabol.2013.09.002

20. Bellisle F. Intense sweeteners, appetite for the sweet taste, and relationship to weight management. Curr Obes Rep. 2015;4(1):106-10. DOI: http://dx.doi.org/10.1007/s13679-014-0133-8

21. Feijó FM, Ballard CR, Foletto KC, Batista BA, Neves AM, Ribeiro MF, et al. Saccharin and aspartame, compared with sucrose, induce greater weight gain in adult Wistar rats, at similar total caloric intake levels. Appetite. 2013; 60(1):203-7. DOI: http://dx.doi.org/10.1016/j.appet.2012.10.009

22. Swithers SE, Sample CH, Davidson TL. Adverse effects of high-intensity sweeteners on energy intake and weight control in male and obesity-prone female rats. Behav Neurosci. 2013;127(2):262-74. DOI: http://dx.doi.org/10.1037/a0031717

23. Shukla AP, Buniak WI, Aronne LJ. Treatment of Obesity in 2015. J Cardiopulm Rehabil Prev. 2015;35(2):8192. DOI: http://dx.doi.org/10.1097/HCR.0000000000000112

24. Roberts JR. The Paradox of Artificial Sweeteners in Managing Obesity. Curr Gastroenterol Rep. 2015;17(1):423. DOI: http://dx.doi.org/10.1007/s11894-014-0423-z

25. Gardner C. Non-nutritive sweeteners: evidence for benefit vs. risk. Curr Opin Lipidol. 2014;25(1):80-4. DOI: http://dx.doi.org/10.1097/MOL.0000000000000034

26. Ozier AD, Henry BW; American Dietetic Association. Position of the American Dietetic Association: nutrition intervention in the treatment of eating disorders. J Am Diet Assoc. 2011;111(8): 1236-41. DOI: http:// dx.doi.org/10.1016/j.jada.2011.06.016

27. Jain A, Paranjape S. Prevalence of type 2 diabetes mellitus in elderly in a primary care facility: An ideal facility. Indian J Endocrinol Metab. 2013;17(Suppl1):S318-22. DOI: http://dx.doi.org/10.4103/22308210.119647

28. Galante AP, Colli C. Development and use of an on-line semi-quantitative food frequency questionnaire to evaluate calcium and iron intake. Rev Bras Epidemiol. 2008;11(3):402-10. DOI: http://dx.doi.org/10.1590/ S1415-790X2008000300007

This article is distributed under the terms of the Creative Commons Attribution 4.0 International License (http://creativecommons.org/licenses/by/4.0/), which permits unrestricted use, distribution, and reproduction in any medium, provided you give appropriate credit to the original author(s) and the source, provide a link to the Creative Commons license, and indicate if changes were made. The Creative Commons Public Domain Dedication waiver (http://creativecommons.org/publicdomain/zero/1.0/) applies to the data made available in this article, unless otherwise stated. 


\section{Resumo:}

Introdução: O consumo de açúcares adicionados aumentou em todo o mundo. Para orientar e encorajar a implementação de políticas públicas no consumo de adoçante não nutritivo (NNS), é necessário não apenas identificar a quantidade consumida desses produtos, mas também os fatores associados ao seu consumo.

Objetivo: Este estudo teve como objetivo identificar as variáveis relacionadas ao consumo de NNS no estado de São Paulo, Brasil.

Método: Realizou-se um estudo transversal envolvendo funcionários adultos de duas universidades públicas do Estado de São Paulo, Brasil. Foi aplicado um questionário on-line contendo perguntas sobre o uso de NNSs e informações sobre características demográficas, socioeconômicas, antropométricas e de saúde. As análises estatísticas realizadas incluíram: o teste do qui-quadrado para determinar a associação entre variáveis explicativas e dependentes, adotando-se um nível de significância de $p<0,05$ e regressão logística binária, calculando Odds-Ratio (OR) $(\alpha=0,05)$. Resultados: Participaram do estudo 1323 indivíduos. A prevalência de uso de NNS foi de 53,3\%, mostrando-se maior entre indivíduos de 30 a 60 anos de idade $(83,3)$. O teste de Qui-quadrado revelou que as variáveis gênero $(p=0,000)$, Diabetes Mellitus ( $p=$ Hipertensão arterial $(p=0,008)$, dificuldade de controle de peso $(p=0,000)$, IMC $(p=0,000)$, renda $(p=0,002)$ e idade $(p=0,000)$ apresentaram associação direta e significativa com o consumo de NNS. (OR = 2,59), DM $(O R=3,32)$, dificuldade de controle de peso $(O R=2,29)$ e consumo de alimentos dietéticos $(O R=3,87)$. Estes resultados revelaram que as muIheres são 30\% mais propensas a consumir NNS do que os homens e que estando entre os 50 e 60 anos aumenta a probabilidade de consumir estes produtos em 2,59 vezes. Além disso, sendo diabético, ter dificuldade em controlar o peso corporal e consumir dieta alimentar, aumentam a probabilidade de consumo de NNS em 3,32, 2,29 e 3,97 vezes, respectivamente.

Conclusão: A maioria da população estudada era consumidorea de NNSs. As variáveis gênero, idade, DM, dificuldade em controlar o peso corporal e consumo de alimentos dietéticos foram todas associadas ao consumo de NNSs.

Palavras-chave: adoçantes não nutritivos, obesidade diabetes mellitus, peso corporal. 